\title{
CHYLOTHORAX IN THE NEWBORN
}

\author{
BY \\ J. SAKULA \\ From the Central Middlesex Hospital, London
}

(Received for Publication September 6, 1949)

Chylothorax in infancy is an extremely rare condition and a search of the literature has only revealed 13 cases under the age of one year, of which five occurred in the first four weeks of life (Table 1). Only two of these infants survived, and therefore the publication of a further case of a child four days old who recovered spontaneously after two aspirations, seems justified.

\section{Case Report}

J.K., a doctor's first child, after an uncomplicated pregnancy, was born at term on June 19, 1948, by forceps delivery for delay in the second stage of labour. The child was asphyxiated at first and responded slowly to routine treatment, but he was crying well 20 minutes after birth. He weighed $7 \mathrm{lb}$. $6 \mathrm{oz}$. and externally appeared quite normal, apart from a small right-sided hydrocoele and a small vascular naevus on the back.

After $\mathbf{4 8}$ hours he was put to the breast, and, although he seemed to suck well, it was noticed that during feeding he became slightly cyanosed with rapid respirations. Examination of the chest at this time showed no grossly abnormal signs. During the next two days, however, the cyanotic attacks became more frequent and occurred after crying as well as after feeding. Examination of the chest now showed dullness of the right chest with diminished air entry, and a radiograph revealed a rightsided pleural effusion.

Needling was performed on the morning of the fifth day and $45 \mathrm{ml}$. of slightly opalescent, yellowish coloured fluid was aspirated and replaced with 100,000 units of pure penicillin. The fluid was found to contain $4 \%$ protein, but no fat. There were many cells, mainly lymphocytes. No organisms were seen in the direct film and the culture remained sterile.

Following the aspiration, the child was immediately more comfortable and cyanotic attacks were less frequent. On the seventh day a second radiograph still showed a fair amount of fluid, but further needling was not very successful and only a few millilitres of fluid were obtained. It was, however, noticed that the fluid was becoming more opaque.

By the tenth day the cyanotic attacks had become more frequent again. A further aspiration, taking off as much as possible, produced $90 \mathrm{ml}$. of odourless, milky fluid, only very slightly yellowish in colour. This fluid when analysed now gave the typical findings of chyle; protein $4 \mathrm{~g}$. per $100 \mathrm{ml}$., cholesterol $48 \mathrm{mg}$. per $100 \mathrm{ml}$., fat $0.9 \mathrm{~g}$. per $100 \mathrm{ml}$.; cells, a few lymphocytes only.
The fat was present in very fine emulsion, and there was no apparent alteration in the appearance of the fluid on standing or after filtration through a Whatman's filter No. 42, but a clear yellow fluid was obtained from Berkefeld filtration.

One week later the child seemed much better and there had not been any further attacks of cyanosis. X-ray examination showed no further collection of fluid. At the age of 24 days he was discharged home, fully breastfed and gaining weight, and his last radiograph was perfectly clear. Shortly after this he was taken to Canada, and at the age of six months he was perfectly fit, weighed $18 \mathrm{lb}$. and had a clear chest radiograph.

TABLE 1

Table of Reported Cases of Chylothorax in Neonates

\begin{tabular}{|c|c|c|}
\hline Case & $\begin{array}{c}\text { Age } \\
\text { (days at } \\
\text { onset) }\end{array}$ & Outcome \\
\hline $\begin{array}{l}\text { Stewart and Linner } \\
\text { (1926) }\end{array}$ & 4 & $\begin{array}{l}\text { Died after repeated } \\
\text { daily aspirations for } \\
16 \text { days. }\end{array}$ \\
\hline Hilgenberg (1929) & 5 & $\begin{array}{l}\text { Diagnosed at } \\
\text { necropsy. }\end{array}$ \\
\hline $\begin{array}{l}\text { Janet, Boegner, and } \\
\text { Laquerrière (1936) }\end{array}$ & 21 & $\begin{array}{l}\text { Recovered after one } \\
\text { aspiration. }\end{array}$ \\
\hline $\begin{array}{l}\text { Everhart and Jacobs } \\
\text { (1939) }\end{array}$ & 15 & $\begin{array}{l}\text { Died after repeated } \\
\text { aspirations for three } \\
\text { weeks. }\end{array}$ \\
\hline Wessel (1944) & 14 & $\begin{array}{c}\text { Recovered after } 13 \\
\text { daily aspirations. }\end{array}$ \\
\hline Present case & 4 & $\begin{array}{l}\text { Recovered after two } \\
\text { aspirations. }\end{array}$ \\
\hline
\end{tabular}

\section{Discussion}

That this was a case of chylothorax was subsequently quite obvious, but the diagnosis was not immediately made at the first aspiration because the fluid did not look like chyle and was orange-yellow in colour. It appears, however, that this coloration has been noticed previously in neonatal cases. Stewart and Linner (1926) thought that it was due to pigment (lactochrome) present in the colostrum, but this is unlikely, for the amount of coloration is too great to be accounted for by the small amount of pigment in colostrum, and attempts to colour 
chylous pleural effusions by administering dyes by mouth have not been successful. The subsequent change in colour and appearance of the fluid to resemble milk is due to the increase in the amount of fat which is present in a fine emulsified globular state. In the first specimen of fluid obtained in this case, no fat globules could be seen at all and. it was reported that the fluid resembled lymph. Apparently it was not till after the child had been on the breast for a few days that fat was being absorbed and passed via the thoracic duct into the pleural cavity. It can easily be shown in cases where the chylous effusion tends to recur after aspiration that the fat content of the chyle varies with the fat content of the diet.

The aetiology of these cases is still obscure. In early infancy they are usually designated as 'spontaneous' which really means that they are of unknown origin. After this age practically all cases of chylothorax are associated with injury. The injury is usually serious, but occasionally, especially in children, it may be only slight. Thus Kirchner (quoted by Janet, Boegner, and Laquerrière 1936) reports the case of a child of nine years who was pushed by another child against a window bar and 15 days later developed a chylothorax. Muttermilch (1902) writes of a five-months-old infant who was dropped out of bed by its mother and in falling knocked against its cradle. It was apparently normal for two to three weeks and was then found to have a chylothorax. In the case of Everhart and Jacobs (1939), delivery was complicated by cyanosis of the child due to the cord being tightly round the neck and it required vigorous attempts by the accoucheur to revive the child. In the other neonatal cases all the deliveries were quite normal. In this case the child was delivered by forceps, and showed slight asphyxia which responded slowly, but no vigorous methods of resuscitation were employed. It is possible, however, that in all these cases the child may have sustained some mild injury at birth, even possibly hyperextension of the spine or compression of the chest, but sufficient to injure the lower part of the thoracic duct when it is specially fragile due to a congenital weakness or defect.

In all the neonatal cases the child appeared to be quite well to begin with, and then after an interval of time, varying between four and twentyone days, developed a fairly sudden onset of dyspnoea due to rapid formation of a right-sided pleural effusion. It should be noted that in the cases where chylothorax follows a definite injury, there is always a delay before the sudden appearance of the pleural effusion. This delay is usually two to ten days, but may even be up to three weeks or longer. It is difficult to explain this interval of time, but it may be associated with the fact that the thoracic duct is anatomically extrapleural in position. It has been suggested that the interval represents the time required for erosion and perforation of the contiguous pleura by the enlarging retropleural collection of chyle. This suggestion would explain the delay in the onset of the development of the chylothorax in the neonatal cases if it is agreed that it is the result of an injury at birth.

The progress in these cases is interesting in that three of the cases recovered after simple repeated aspirations presumably by the spontaneous closure of the fistula. The case of Janet etal. (1936) recovered after one aspiration, that of Wessel (1944) after 13, and this case after two. In the adult, traumatic chylothorax has been treated successfully by the ligation of the thoracic duct (Baldbridge and Lewis, 1948), but this would be impossible in infantile cases. Repeated aspirations seem to be the only line of treatment, but should these have to be continued for a long time, then the maintenance of nutrition becomes essential but will be difficult owing to the persistent loss of fluid, fat, and protein.

\section{Summary}

A case of chylothorax in a neonate is described. Spontaneous recovery occurred after two aspirations. The aetiology is discussed, and it is concluded that the condition in neonates is most likely to be the result of a birth injury to the thoracic duct.

\section{REFERENCES}

Baldbridge, R. R., and Lewis, R. V. (1948). Ann. Surg., 128, 1056.

Everhart, J. K., and Jacobs, A. H. (1939). J. Pediat., 15, 558.

Hilgenberg, F. C. (1929). Mschr. Gerburtsch. Gynäk.. $83,225$.

Janet, H., Boegner, E., and Laquerrière, Mme (1936). Bull. Soc. Pédiat., Paris, 34, 577.

Kirchner. (Quoted by Janet, Boegner, and Laquerrière.)

Muttermilch, S. (1902). Z. klin. Med., 46, 122.

Stewart. C. A., and Linner, H. P. (1926). Amer. J. Dis. Child., 31, 654.

Wessel, M. A. (1944). J. Pediat., 25, 201. 